\title{
Relationship between remittances and rural primary education: a case study on a group of remittance beneficiaries
}

\author{
M. A. M. I. Perera* and M. Wijeratne \\ Department of Agricultural Economics \& Extension, Faculty of Agriculture, University of Ruhuna, Matara, Sri Lanka.
}

\begin{abstract}
Today nearly two million Sri Lankans are employed abroad generating US Dollars 7 million annually, accounting for 8 percent of Gross Domestic Product. Most of the studies pertaining to Sri Lanka are confined to the benefits of migration on rural communities and members left behind by increasing household income. However, there is little focus on the impact of remittance on educational productivity. In this context, this study was conducted with the main objective of investigating the impact of remittance on primary education in rural community. The data collection was conducted using a pre-structured questionnaire in Galewela Divisional Secretarial with a sample of 45 households receiving remittances through a selected private bank and another 45 households who are non- recipients of remittances with children obtaining primary education. The findings of the study revealed that migrant households spend a higher proportion of remittances on primary education than non-migrant households. It was found that according to the parental perception of migrant families, the productivity of rural primary education has increased after the investment of remittances. But according to the statistical comparison using two sample t- test focused on the level of primary education among migrant and non-migrant families, it is revealed that remittances have no significant impact on the productivity of rural primary education. Through the regression analysis conducted to find the factors affecting rural primary education, it was concluded that parental absence and time allocation of mother for children's education play an important role than the share of remittances allocated for education.
\end{abstract}

Keywords: Remittance, rural, primary education.

\section{INTRODUCTION}

There are numerous factors which contribute significantly to the improvement of the society's standards of living and further, some of these factors have a special relevance for a particular community. One such factor is remittance inflows to developing countries because they contribute conspicuously in the economic upliftment of the households and overall economy in the poor countries. According to International Organization of Migration (IOM, 2008), remittances are defined as monies earned or acquired by non-nationals that are transferred back to their country of origin. As foreign aid continues to shrink, while Foreign Direct Investment (FDI) flows remain vulnerable to the vicissitudes of global economic developments, remittances have proven to be a more stable source of foreign exchange for many developing countries.

The impact of remittances should be addressed at both macro and micro levels. According to Jayawardane (2012), at the macro level, remittance inflows are an important source of external financing for developing countries, often providing a steady source of capital in excess of funds generated through overseas development assistance, FDI and portfolio inflows. In addition to being a steady source of capital, remittances go directly to the target group, mainly the rural poor at grass root level with the potential to have a significant increase in their incomes. Remittance inflows to Sri Lanka have increased steadily over the last 20 years playing counter cyclical role, rising in times of global economic downturns when a country faces a domestic shock. Remittance inflows have also persistently contributed to support Sri Lanka's balance of payments (BOP).

Remittances have a micro-level impact on the country of origin in several respects such as easing deprivation in meeting basic needs of households, increasing their ability to cope with adverse shocks, allowing them to 
purchase land or other productive assets, releasing them from indebtedness, promoting small scale enterprise development and increasing investment in health and education. The number of total migrants from Sri Lanka rose significantly from 1980s due to various political and economic reasons, and at the same time remittance flow to the country has also increased continuously. The remittance flow to Sri Lanka from 2000- 2015 is mentioned in Figure 1.

Figure 1: Private remittances

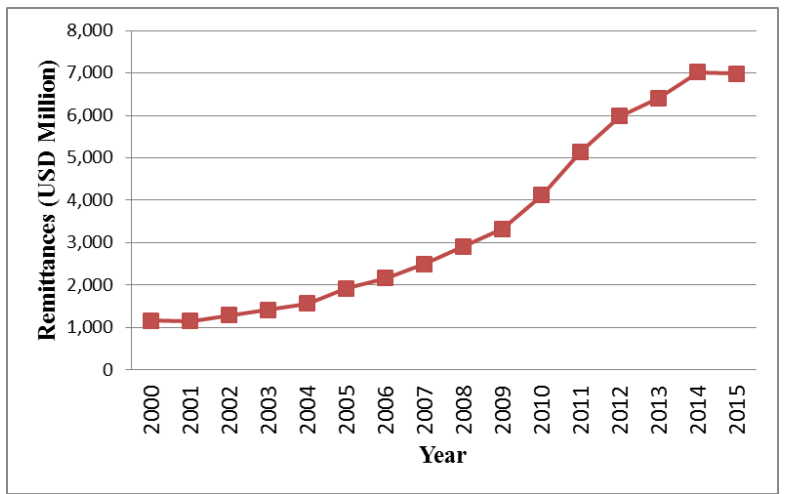

Source: Ministry of Foreign Employment (2015)

According to Cotula et al. (2004), household members in migrant families spend remittances in various ways in order to increase access to other capital assets other than financial capital. They want to enhance their human capital (eg: education), physical capital (eg: equipment, building), natural capital (eg: purchase land), social capital (eg: forming social network). Therefore, it is necessary to distribute the remittances proportionately among the necessities of the household members to use them productively. While remittances to the country is continuously increasing for years, highest proportion of such funds is allocated for the non-food items while lowest proportion is allocated for the education (Figure 2). However, it is questionable why the lowest proportion

Figure 2: Allocation of remittance expenditure in households

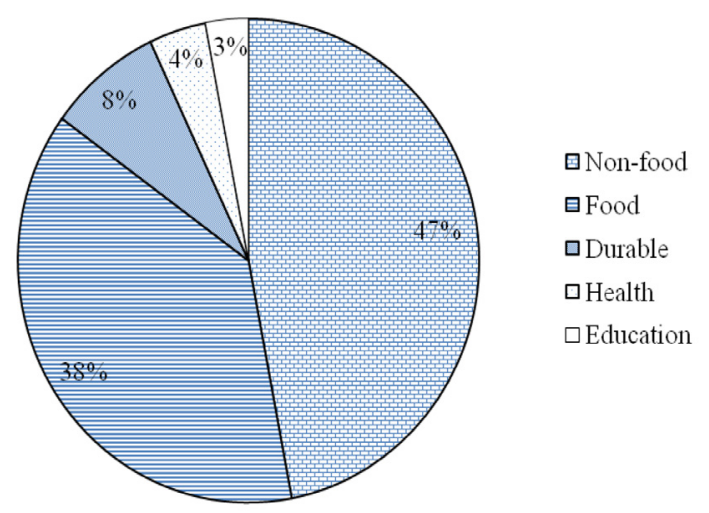

Source: Jayawardane (2012) of remittances is used for the education. Little attention is paid on previous studies regarding the impact of remittance on education due to difficulties in gathering accurate data and lack of availability in official data. Therefore, in this study, it is attempted to find the impact of remittances on rural primary child education.

The general objective of the study is to investigate the impact of remittances on rural primary child education. As the general objective is broader, it is categorised into specific objectives mentioned below.

1. To identify the contribution of remittances for primary child education.

2. To examine the productivity of remittance investments on education.

3. To compare the level of primary child education among migrant and non-migrant families.

Figure 3 illustrates the conceptual framework of the study. The study focuses on the share of remittances allocated for the primary education and its outcome. It aims on finding the factors that affect the productivity of primary child education.

Figure 3: Conceptual Framework of the research

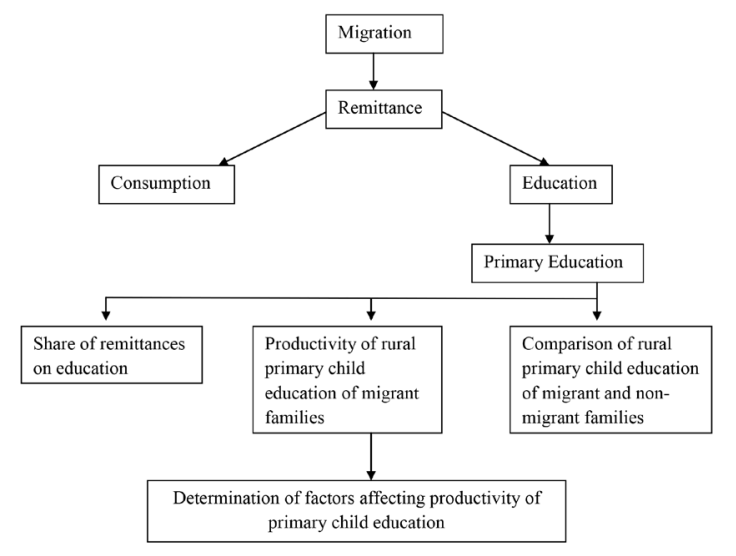

REVIEW OF LITERATURE

Present status of the primary education

Primary education is the foundation for all education systems. Therefore, primary education in a country should be improved for development of the entire education system. According to Liyanage (2014), it has been revealed that approximately $6.19 \%$ in the compulsory school going age (5-14 years of age) do not attend school. According to UNICEF (2013), primary school children have achieved low levels in basic numeracy and literacy. This implies that the prevailing 
primary education system does not provide students who are appropriate for the successful living enriched with knowledge, skills and attitudes. At the same time, total personality development characterised by discipline, respect, tolerance, team spirit, creativity is not achieved.

Although the above mentioned figures are national averages, in reality it includes pockets where the percentage of non-attendance is very much higher. Referring to Liyanage (2014), previous studies have shown that there are multiple reasons for this condition which are mostly due to the socio-economic and poverty issues that require children to participate in income generating activities in order to supplement the family income. Especially girls in this age group are kept in home to look after the younger children and engage in household activities such as cooking, washing clothes etc. As well as non-attendance is also higher in sowing and harvesting seasons of crops related to agricultural activities where child labour is highly demanded. On the other hand, children have been prevented from gaining admission to school due to lack of documents like birth certificate. Furthermore, World Bank (2013) stated that most of the students fail to complete Grade 5 are from poor families, economically disadvantaged regions, rural areas, conflicted-affected provinces and estate sector. They affect the background of learners, their participation in education, the expression of their potential and their levels of achievement.

\section{Impact of migration on education in Sri Lanka}

Migration affects education in both positive and negative manners as revealed from the study by Arunatilake et al. (2010). It reveals that although investments on education are increased due to migration as wealth of people are increased, migration of parents can leave families of young children with inadequate guidance and an additional burden of household responsibilities which can lead to higher rate of school absenteeism and school drop outs. After the migration of parents, the remaining household activities such as cooking, washing, caring of younger children are loaded on the elder children in the families, especially on the girls, that results in reduction in time allocated for the education and the children are subjected to physical and emotional abuse, sexual harassment, rape, misbehaviors etc. This Sri Lankan context can be supported by the evidences in China deriving the same results. According to $\mathrm{Hu}$ (2013), absence of an adult household member may increase children's level of involvement in household chores and income generating activities. Same results were revealed by Nasir et al. (2011) in two aspects: one aspect implies that after the migration of parents, children forward to fulfill all the responsibilities previously held by the parents, which becomes a hurdle in their education as a significant amount of time allocated for children's education is occupied by the responsibilities. The second aspect implies that absence of parental attention badly affects the children's performance in the school which can be especially observed in nuclear families where absence of father may lead to the adaptation of bad company by the children, as the mother finds it difficult to keep a hold on the children outside the home while managing the household activities. These aspects ultimately lead to the drop out of children from the school.

\section{Impact of remittance on the education in Sri Lanka}

The importance of remittances as a source of income in Sri Lanka is undeniable. In Sri Lanka, researches regarding remittances are restricted to the areas of Gross National Product (GNP) growth, private savings, private investments, consumption. According to Arunatilake et al. (2010), remittance flows may serve to stabilise recipient economies at times of economic downturns brought on by such phenomena as a natural disaster, financial crisis and migrant households are better off compared to nonmigrant households, since migrant households receive a higher level of income from properties, financial and physical assets. But the debate over the effects of remittances on education of the children of migrants' remains controversial.

The most important question that should be addressed is the impact of remittances on education in Sri Lanka. The existing evidence shows only a descriptive analysis and the proportion of remittances spent on education can be revealed. Comparison of the expenditure on health and education by migrant and non-migrant households reveals that average investments on health and education are indeed higher for migrant households at statistically significant levels (Jayawardana, 2012). But when investigating the school enrolment and morbidity level indicators, they did not show statistically significant difference between migrant and non-migrant households at the national or sub-national levels. It was suggested to conduct further studies to investigate the difference between education levels between migrant and nonmigrant families and the reasons for the obtained results.

\section{METHODOLOGY}

In order to fulfill the objectives of this study, two target populations were observed: remittance beneficiaries and non- recipients of remittances. Due to the limited availability of time and resources, the sample of 45 remittance beneficiaries was restricted to a selected commercial bank. The geographical area covered 
under this study was Galewela Divisional Secretariat in Kurunegala District, North Western Province. Kurunegala District was reported as one of the districts with the highest number of migrant workers (Sri Lanka Bureau of Foreign Employment, 2014). Galewela Divisional Secretariat was selected purposively for the study as it was permitted to meet the remittance beneficiaries in Galewela branch of the selected commercial bank. The sample of non- receivers of remittances was also selected from Galewela Divisional Secretariat.

In the selection of samples, multistage sampling technique was used including purposive sampling and simple random sampling with each sample containing 45 respondents. Data collection was done through both primary and secondary methods. Primary data collection was done through household survey questionnaires and formal interviews. Secondary data were obtained from relevant bank Head Office in Colombo, its branch in Galewela, published information from internet, journals and newspapers. The data were analysed using descriptive methods, Wilcoxon sign rank test, two sample t- test and regression analysis.

\section{RESULTS AND DISCUSSION}

\section{Personal background of the migrants}

According to the collected information, migrated countries were categorised into four major regions as European, Middle East, Far East and Australia. It was revealed that a highest number of migrants $(76 \%)$ is recorded from the Middle East region including the countries Dubai, Kuwait, Lebanon, Oman, Qatar and Saudi Arabia. The second highest number of migrants $(11 \%)$ is recorded from both Far East region and European region. Far East region includes the countries Singapore and Korea. European region includes the countries Cyprus and New Zealand.
Table 1: Manpower levels of the migrant workers abroad

\begin{tabular}{ll}
\hline Manpower level & Percentage (\%) \\
\hline Professional & 4 \\
Semi-skilled & 15 \\
Unskilled & 16 \\
Housemaids & 65 \\
\hline
\end{tabular}

Referring to the Table 1, the total sample can be categorised according to the manpower levels and it implies that majority are occupied as housemaids (65\%), unskilled employees $(16 \%)$ and very small percentage is occupied as professionals (4\%).

Table 2: Household size of the migrants

\begin{tabular}{lll}
\hline Household size & Frequency & Percentage (\%) \\
\hline 2 & 2 & 5 \\
3 & 13 & 29 \\
4 & 19 & 42 \\
5 & 8 & 17 \\
6 & 3 & 7 \\
\hline
\end{tabular}

According to Table 2, household size in the target population varies from 2 to 6 . Highest household size is 4 including parents and two children. Second highest household size is 3 including parents and one child. Smallest household size 2 depicts the parental death in the family. Household size 6 implies the presence of highest number of children in the family.

\section{Information on parents in migrant and non-migrant families}

As mentioned in Table 3, level of mother's education is higher than the level of father's education in the selected sample. Anyhow, as the education backgrounds could be varying accordingly with the samples, the

Table 3: Education background of parents

\begin{tabular}{lllllllll}
\hline \multirow{2}{*}{$\begin{array}{l}\text { Education } \\
\text { level of } \\
\text { parents }\end{array}$} & \multicolumn{3}{c}{ Migrant families } & \multicolumn{5}{c}{ Non-migrant families } \\
\cline { 2 - 9 } & F & P (\%) & F & P (\%) & F & P (\%) & F & P (\%) \\
\hline Grade 0-5 & 1 & 2 & 5 & 11 & 2 & 4 & 10 & 22 \\
Grade 6-8 & 17 & 38 & 9 & 20 & 7 & 16 & 10 & 22 \\
Grade 9-11 & 16 & 36 & 16 & 36 & 24 & 53 & 14 & 32 \\
Grade12-13 & 10 & 22 & 5 & 11 & 11 & 25 & 11 & 24 \\
Graduate & 1 & 2 & 2 & 4 & 1 & 2 & 0 & 0 \\
\hline
\end{tabular}


variation among the level of education would have been observed much clearly and reliably with a sample of higher population.

According to Table 4, the parental expectation on child education was investigated from both migrant and nonmigrant families and it varies from Grade $0-5$ to Graduate level. It indicates that the highest number of mothers and fathers in migrant families expect their children to be educated up to Graduate level. In non-migrant families, parental expectation of child education up to Graduate level of mothers and fathers has been reduced when compared with migrant families. Therefore, it can be assumed that parental expectation on child education for further studies is higher in migrant families than the non-migrant families due to their exposure to outside environment as a result of migration. Totally, expectation on child education in mothers is higher than in fathers.

As shown in Table 5, there is a considerable difference between the parental time allocations for children in migrant and non-migrant families. In father-migrated families, majority of mothers spend more time on the children than fathers in mother-migrated families. In some migrant families, grandparents are the care takers of the children as the mother has migrated and father has died. Therefore, it can be assumed that children in father-migrated families perform better than children in mother-migrated families due to presence of mother guidance. In non-migrant families, highest percentage of mothers spends more time than fathers on behalf of children education.

Table 4: Parental expectation on child education

\begin{tabular}{lllllllll}
\hline \multirow{2}{*}{$\begin{array}{l}\text { Parental } \\
\text { expectation on } \\
\text { child education }\end{array}$} & Mother & Father & Mother & Father & Mother & Father & Mother & Father \\
\cline { 2 - 9 } & $\mathrm{F}$ & $\mathrm{P}(\%)$ & $\mathrm{F}$ & $\mathrm{P}(\%)$ & $\mathrm{F}$ & $\mathrm{P}(\%)$ & $\mathrm{F}$ & $\mathrm{P}(\%)$ \\
\hline Grade 0-5 & 0 & 0 & 0 & 0 & 0 & 0 & 0 & 0 \\
Grade 6-8 & 0 & 0 & 0 & 0 & 0 & 0 & 0 & 0 \\
Grade 9-11 & 1 & 2 & 3 & 7 & 0 & 0 & 9 & 20 \\
Grade 12-13 & 5 & 11 & 4 & 9 & 15 & 34 & 22 & 49 \\
Graduate & 39 & 87 & 38 & 84 & 29 & 64 & 13 & 29 \\
\hline
\end{tabular}

Table 5: Parental time allocation for child education

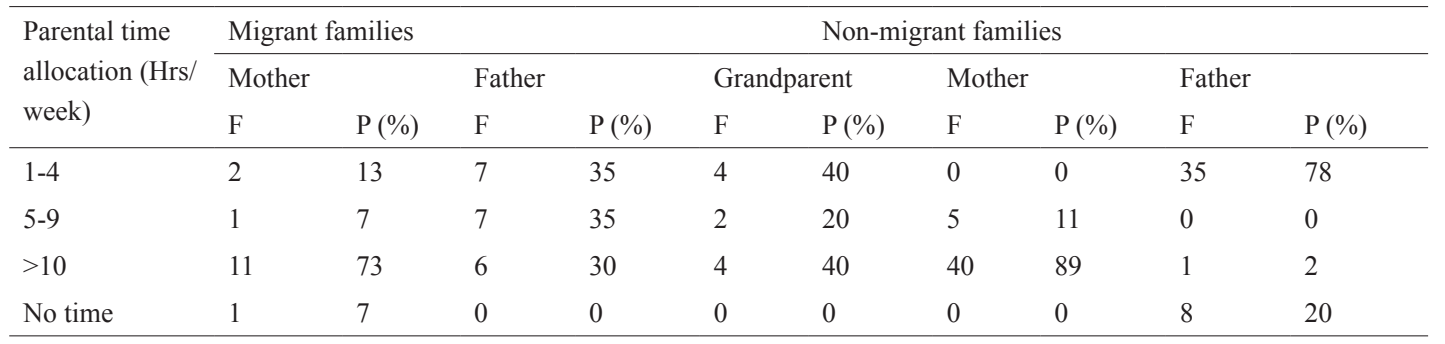

Table 6: Comparison of monthly remittance contribution to the consumption and education

\begin{tabular}{lll}
\hline Remittance contribution (\%) & Number of families (\%) \\
\cline { 2 - 3 } & Consumption & Education \\
\hline $0-10$ & 2 & 0 \\
$11-20$ & 0 & 13 \\
$21-30$ & 0 & 27 \\
$31-40$ & 2 & 24 \\
$41-50$ & 16 & 16 \\
$51-60$ & 18 & 16 \\
$61-70$ & 32 & 2 \\
$71-80$ & 31 & 0 \\
$81-90$ & 9 & 0 \\
$91-100$ & 0 & 2 \\
\hline
\end{tabular}


According to Table 6, there are two types of families; one which spends on consumption more than on education and the other vice versa. Totally $92 \%$ of families spend higher proportion of remittances for consumption than education and only $66 \%$ of families spend higher proportion of remittances for education than consumption. This can be supported by the evidence of Jayawardane (2012) stating that although remittances to the country is continuously increasing for years, in considering about the remittance expenditure, highest proportion is allocated for the non-food items while lowest proportion is allocated for the education.

Table 7 illustrates the average monthly expenditure for education among migrant and non-migrant families. Average monthly expenditure for education is higher in migrant families than non- migrant families.

\section{Productivity of remittance investments on education}

The respondents in this survey were the remaining parents or care takers of the children in migrant families. In order to examine the productivity of remittance investments on education, parental perception on children education improvement in five criteria was investigated.

\section{(1) Improvement in academic records of children}

Academic records are an indicator to measure the improvement in children education. Improvement in academic records of children was measured according to the feedback of parents. $22 \%$ of parents admitted that academic records of children have been improved after the remittance investment (Wilcoxon Sign Rank Test Value $=5.824, \mathrm{p}$ value $=0.000) .18 \%$ of parents admitted that academic records of children have been decreased and $60 \%$ of parents have no idea on that criterion.

\section{(2) Improvement in children participation to extracurricular activities}

According to Little (2000), basic competencies in primary child education comprise sports and athletics, indoor games, aesthetics, creative activities. 67\% of parents mentioned that children participation to extracurricular activities has been improved significantly because investment on education has been increased due to the remittances and parents have realised the benefits of extracurricular activities on the children's future life (Wilcoxon Sign Rank Test Value $=5.819, \mathrm{p}=0.0000$ ) $11 \%$ of parents admitted that children participation to extracurricular activities has been decreased and $22 \%$ of parents admitted that there has been no change.

\section{(3) Improvement in children personality development}

$\mathrm{Hu}$ (2013) reported that children seem to benefit from remittances which ease the liquidity constraints on rural households, freeing up more money for investment in the children's education. Child personality is improved due to remittances because children are motivated as a result of continuous monthly delivery of money and enhancing the social relationships. $71 \%$ of parents admitted that children personality has been improved significantly due to remittances (Wilcoxon Sign Rank Test Value $=5.705$, $\mathrm{p}=0.0000) .11 \%$ of parents mentioned that children personality development has been decreased and $18 \%$ of parents stated that there has been no change.

\section{(4) Improvement in children encouragement to the education}

According to parental perception, 31\% of parents admitted that children encouragement to the education has been improved after the remittance investment to the

Table 7: Average monthly expenditure for education

\begin{tabular}{lll}
\hline Component & \multicolumn{2}{c}{ Average monthly expenditure (SLRs) } \\
\cline { 2 - 3 } & Migrant families & Non- migrant families \\
\hline Tuition classes & 1978 & 1381 \\
School fees & 194 & 88 \\
School books & 850 & 378 \\
School stationaries & 647 & 312 \\
School transport & 512 & 351 \\
School uniform & 54 & 0 \\
School shoes & 0 & 0 \\
School bags & 0 & 0 \\
School lunch & 1580 & 1541 \\
Extra-curricular activities & 788 & 369 \\
Total & 6603 & 4420 \\
\hline
\end{tabular}


education (Wilcoxon Sign Rank Test Value $=5.836, \mathrm{p}$ $=0.0000) .53 \%$ of parents mentioned that they did not notice any improvement in children encouragement and $16 \%$ of parents stated that children encouragement has been increased.

\section{(5) Improvement in children participation to tuition classes}

According to the findings of $\mathrm{Hu}$ (2013), it has been reported that the possibility of attending out-of-school tutoring is greater for children in migrant households than for those in non-migrant households. According to the collected information, $82 \%$ of parents admitted that children participation to tuition classes has been significantly improved (Wilcoxon Sign Rank Test Value $=5.771, \mathrm{p}=0.0000) .11 \%$ parents admitted that it has been declined and $7 \%$ of parents admitted that there has been no change.

\section{The level of primary child education among migrant and non-migrant families}

According to the previous findings, it was clearly revealed that remittance investment has improved the performance of child education according to parental perception. But $\mathrm{Hu}$ (2013) has discovered that there is no significant impact of remittances on education when comparing the migrant and non-migrant households. Therefore, using the collected information, performance of child education was compared among migrant and non-migrant families using five criteria: improvement in academic records, improvement in children participation to extracurricular activities, improvement in children personality, improvement in children encouragement for education, improvement in children participation to tuition classes. This is confirmed by analysing the responses using two samples T-test at 5\% significance level (Table 8). The hypotheses were as follows.

$\mathrm{H}_{0}$ : Remittance investment has no impact on child education performance.
$\mathrm{H}_{1}$ : Remittance investment has an impact on child education performance.

Statistically, the hypothesis testing indicates that remittance investment has no impact on child education performance as all these are not statistically significant at $5 \%$ significance level. Therefore, it signals the presence of some other factors that affect the performance of child education other than remittances and it is worth to identify the main variables which affect to this scenario. A regression analysis was done in order to interpret the most significant variables that affect to the performance of education.The variable "parental relationship of the migrant to the children" was included as a dummy variable: " 1 " for mother and " 0 " for father.

The above mentioned regression equation shows that improvement in performance of child education positively depends on share of remittances on education with a coefficient of 0.00147 , time allocation of mother for children education with a coefficient of 0.70996 and negatively depends on the variable: parental relationship of the migrant to the children with a coefficient of 4.1444 (Table 9).

According to the coefficient analysis, most decisive factors that affect the children education are parental relationship of migrant to the children and time allocation of mother for children education than the share of remittances to the education. Therefore, it is clearly revealed that remittance income does not play a significant role in children education with parental absence due to remittances which is detrimental for households' educational performance. At the same time, it is depicted that child education performance is enhanced with the presence of mother in the family with children and her attention on children education. According to Nasir et al. (2011), it is the mother who stays at home and gives proper attention to the children and father, on the other hand, remains in the market for most of the time and may not play a significant role in the children education except for earning income to be spent

Table 8 : Comparison of the level of primary child education among migrant and non-migrant families

\begin{tabular}{ll}
\hline Criteria & P Value ** \\
\hline Improvement in children academic records & 0.3694 \\
Improvement in children participation to extracurricular activities & 0.2094 \\
Improvement in children personality development & 0.3066 \\
Improvement in children encouragement for education & 0.3312 \\
Improvement in children participation to tuition classes & 0.2951 \\
\hline
\end{tabular}

P value**- $P$ values of two sample T-test 
Table 9: Regression analysis for factors affecting productivity of primary education

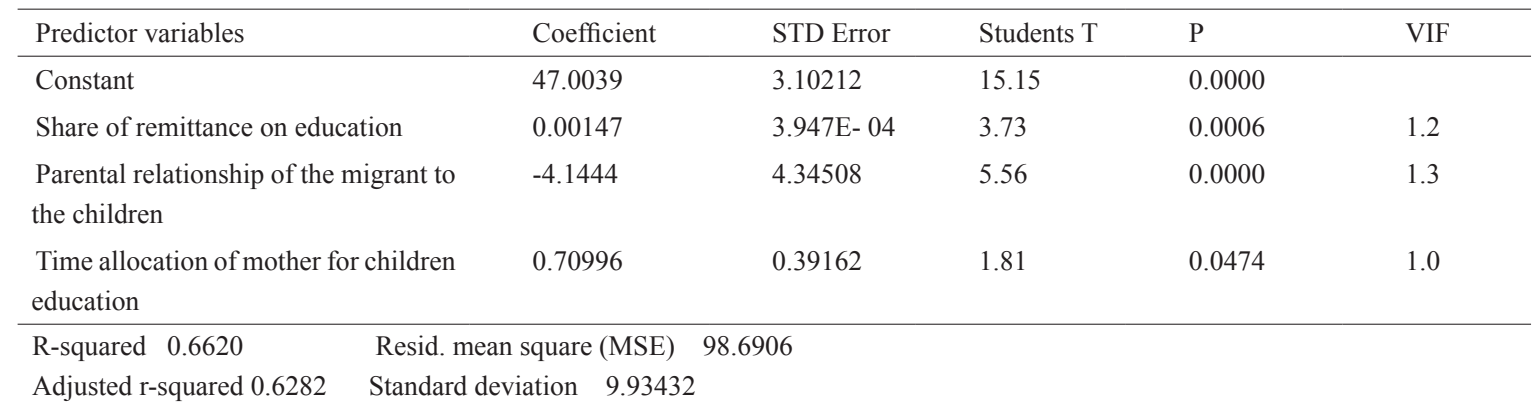

on their educational expenditure. Therefore, presence of mother in the family is essential for the improvement in children education in order to guide the children properly and direct the remittances in an effective manner that can be used in improving the education status of the children.

\section{CONCLUSION}

Based on the field work conducted at Galewela Divisional Secretariat, this study reveals that majority of mothers are migrated than fathers, and their destination countries are almost restricted to Middle East region. Considering the remittance expenditure of migrant households, it concludes that highest proportion of remittances is allocated for consumption and the lowest share is used for education. Remittances for education is allocated for tuition classes fees, extracurricular activities, school fees, school books and stationery, school transport, school lunch and school uniform. Furthermore, it is revealed that expenditure on child education in migrant families is comparatively higher than non-migrant families as the monetary constraints are solved due to remittances and more can be invested on education. According to the parental perception among migrant families, the productivity of children education has been improved after the remittance investment.

Furthermore, statistical comparison of child education productivity among migrant and non-migrant families reveals that there is no significant impact of remittances on child education improvement. Therefore, according to the regression analysis which was conducted to find out the factors affecting children education other than remittance investment, the positive impact of remittances in the form of inflow of income is offset by the negative impact of parental absence, and also the time allocation of mother for children educational activities plays a significant role than the remittance investment as the vacuum created within the family due to absence of father can be filled by a mother to a higher extent by arousing interest in children for education and guiding them properly to certain goals. Therefore, overall educational performance of children would be improved with a combination of remittance receipts and involvement of parents, especially mother's. Further, it is also suggested to explore the context of children's primary education of migrant families in other regions of Sri Lanka in order to enhance their well-being with the collaboration of governmental and non- governmental organisation.

\section{REFERENCES}

Arunatilake, N., Jayaratne, S., Jayawardena, P., Jayaweera, R. and Weerakoon, D. (2010) Impact of remittances on the household of the emigrant and the economy of the migrant's country: Sri Lanka, South Asia network of Economic Research Journal, 10(13), pp: 6-48.

Cotula, D. E., Imai, K., King, G. and Stuart, E. A. (2004) Matching as nonparametric preprocessing for reducing model dependence in parametric causal inference, Political Analysis, 15, pp: 199-236.

Hu, F. (2013) Does migration benefit the schooling of children left behind? Evidence from rural northwest China, Demographic Research Journal, 29, pp: 34-68.

Institute for Public Policy Research for the International Organization for Migration (2008) Migration and Development: Opportunities and challenges for policy makers [Online] Available from: http://publications.iom.int/system/files/pdf/ international_migration_development.pdf [Accessed: 29 $9^{\text {th }}$ April 2017]

Jayawardena, P. (2012) Impacts of remittances on the household of the emigrant: Sri Lanka, Institute of Policy Studies, Sri Lanka.

Little, W. (2000) Access, attendance and achievement in rural schools in Sri Lanka, Monograph Journal, 73, pp: 1-48.

Liyanage, I. M. K. (2014) Education system of Sri Lanka: strengths and weaknesses [Online] Available from: http:// 
s3.amazonaws.com/academia.edu.documents/40870344/0.pd f?AWSAccessKeyId=AKIAIWOWYYGZ2Y53UL3A\&Exp ires $=1496816824 \&$ Signature $=$ keFf8uRuxKQ4S3xNXIuUXh YCWfg\%3D\&response-content-disposition=inline \%3B\%20 filename\%3DEducation_System_of_Sri_Lanka_Strengths.pdf [Accessed: $12^{\text {th }}$ January 2017 ]

Ministry of Foreign Employment. (2015) Annual Performance Report 2015 [Online] Available from: https://www.parliament. $\mathrm{lk} /$ uploads/documents/paperspresented/performance-reportministry-of-foreign-employment-2015.pdf [Accessed: $28^{\text {th }}$ April 2017]
Nasir, M., Tarip, M., Rehman, F. (2011) The effect of foreign remittances on schooling: evidence from Pakistan, PIDE Journal, 66, pp: 5-16.

UNICEF Sri Lanka. (2013) Out- of- school children in Sri Lanka: country study [Online] Available from: https://www. unicef.org/srilanka/2013_OSS.pdf [Accessed: 08 ${ }^{\text {th }}$ January 2017]

World Bank (2013) Advancing Sri Lanka's education system through quality inputs [Online] Available from: http://siteresources.worldbank.org/ SOUTHASIAEXT/ [Accessed: 30 ${ }^{\text {th }}$ January 2017] 